\title{
GREEN CONSUMER BEHAVIOR MASYARAKAT KOTA BOGOR DALAM TATA LAKSANA SAMPAH PLASTIK
}

\author{
Rachman Hendarsyah ${ }^{1 *}$, Ujang Sumarwan ${ }^{2}$, Lilik Noor Yuliati ${ }^{2}$ \\ ${ }^{1}$ School of Business, IPB University, Bogor 16880, West Java, Indonesia \\ ${ }^{2}$ Departemen Ilmu Keluarga dan Konsumen, Fakultas Ekologi Manusia, \\ IPB University, Bogor 16880, Indonesia \\ ${ }^{*}$ E-mail: rachmanh76@gmail.com
}

\begin{abstract}
Abstrak
Peningkatan volume sampah sebesar dua persen setiap tahun telah mendorong berbagai pihak secara aktif melakukan sosialisasi gerakan diet plastik. Penelitian ini bertujuan untuk menganalisis pengaruh sosialisasi (socialization), kesadaran, dan sikap terhadap perilaku konsumen hijau di Kota Bogor dalam pengelolaan sampah plastik. Penelitian dilakukan dengan menyebarkan survei pada Google Form secara daring melalui media WhatsApp dan ditujukan untuk warga Kota Bogor. Teknik pengambilan contoh yang dilakukan adalah nonprobability sampling dengan jenis convenience sampling. Contoh penelitian yang terkumpul sebanyak 223 responden yang diperoleh dari Kecamatan Bogor Utara sebanyak 82 orang, Kecamatan Bogor Tengah sebanyak 49 orang, Kecamatan Bogor Selatan sebanyak 50 orang, dan Kecamatan Bogor Timur sebanyak 42 orang. Data contoh yang terkumpul kemudian divalidasi dan dilakukan analisis menggunakan Structural Equation Model (SEM). Hasil penelitian menunjukkan bahwa perilaku konsumen hijau dipengaruhi oleh sosialisasi, kesadaran, dan sikap. Penelitian ini merekomendasikan agar pemerintah Kota Bogor dapat lebih aktif meningkatkan sosialisasi sebagai variabel yang paling berpengaruh terhadap pembentukan perilaku konsumen hijau warga Kota Bogor dalam pengelolaan sampah plastik.
\end{abstract}

Kata kunci: kesadaran, konsumen hijau, SEM, sikap, sosialisasi

\section{Green Consumer Behavior of Bogor Citizen in Plastic Waste Management}

\begin{abstract}
Increasing a two percent volume of waste in Bogor City has pushed many stakeholders to actively socialize plastic diet. This research was conducted to analyze the effect of socialization, awareness, and attitude on the behavior of green consumers of Bogor Citizen in plastic waste management. The research was conducted online by distributing Google form using WhatsApp. The design of the research is quantitative descriptive-analytic research. Sampling technique using a Non-Probability sampling type of convenience which is sampling based on the availability of samples. At the end of the research obtained 223 respondents from North Bogor Sub-district (82 people), Central Bogor Sub-district (49 people), South Bogor Sub-district (50 people), and East Bogor Sub-district (42 people). The data collected then validated and analyzed by descriptive and quantitative using Structural Equation Model (SEM). The result of the research showed that green behavior is influenced by socialization, awareness, and attitude. This research has pushed the government city of Bogor to act more actively and increase socialization as the most influential variable of green consumer behavior especially on plastic waste management.
\end{abstract}

Keyword: attitude, awareness, green consumer behavior, SEM, socialization

\section{PENDAHULUAN}

Plastik merupakan bahan sintetis yang keberadaannya masih dibutuhkan dalam kehidupan manusia serta belum bisa tergantikan. Masih banyak peralatan manusia yang menggunakan bahan dasar plastik dikarenakan biaya yang dibutuhkan untuk pengolahannya relatif murah dan memiliki sifat tahan lama. Pada tahun 2012 produksi plastik dunia sudah mencapai 288 juta metrik ton per tahun (Jambeck et al., 2015). Jumlah tersebut terus meningkat tajam dan pada tahun 2015 sekitar 6,3 miliar metrik ton plastik telah diproduksi, sebanyak 9 persen didaur ulang, 80 persen terakumulasi menjadi sampah di daratan dan lautan (Geyer, Jambeck, \& Law, 2017). Plastik memiliki banyak nilai ekonomi, bahkan yang sudah menjadi sampah sekalipun masih bisa di daur ulang untuk meningkatkan nilai ekonominya. Sayangnya, tidak semua proses daur ulang plastik memiliki nilai ekonomi 
tinggi. Hal tersebut dikarenakan biaya operasional mesin dan perawatan jauh lebih tinggi daripada hasil daur ulang. Sampah plastik sekali pakai termasuk yang memiliki nilai ekonomi rendah apabila didaur ulang. Oleh sebab itu, setiap orang harus pandai memilah plastik yang digunakan. Plastik sekali pakai dan tidak bisa didaur ulang harus ditinggalkan.

Plastik menghasilkan emisi karbon yang tinggi dimulai dari proses produksi sampai menjadi sampah sehingga berkontribusi terhadap perubahan iklim bumi yang kian lama makin memanas. Pembakaran sampah plastik bisa menyebabkan pencemaran udara dan gangguan pernapasan akibat emisi karbon yang tinggi di udara. Salah satu jenis sampah plastik adalah kantong plastik yang merupakan barang sekali pakai.

Penggunaan kantong plastik secara tidak bertanggung jawab bisa menyebabkan tersumbatnya selokan dan badan air, termakan oleh hewan, rusaknya ekosistem di sungai dan laut. Kantong plastik yang digunakan sebagai wadah makanan berpotensi mengganggu kesehatan manusia karena bahan kimia yang terkandung dalam plastik bersifat racun dan bisa berpindah ke makanan. Kantong plastik dan jenis plastik lainnya memiliki rantai karbon yang panjang sehingga sulit untuk diurai oleh mikroorganisme. Sampah plastik akan terurai ratusan hingga ribuan tahun kemudian, bahkan kantong plastik yang diklaim ramah lingkungan sekalipun akan terurai lama kemudian menjadi mikro plastik yang lebih mudah mencemari lingkungan (Schwarz, Boukris, \& Harmelen, 2019).

Kerusakan lingkungan dan ekosistem dapat disebabkan oleh berbagai hal, salah satunya adalah penumpukan sampah sisa pembuangan atau limbah yang berasal dari industri maupun rumah tangga. Kondisi alam berubah secara signifikan selama 30 hingga 40 tahun terakhir sejak dikenalnya materi sintetis seperti plastik. Menurut Jambeck et al. (2015), Indonesia merupakan negara terbesar kedua penyumbang sampah plastik ke laut setelah Cina. Menurut data yang diperoleh dari Kementerian Lingkungan Hidup dan Perhutanan, pada tahun 2010 volume sampah di Indonesia sudah mencapai 175.000 ton/hari dan 14 persen merupakan sampah plastik.

Pemerintah Indonesia memiliki komitmen untuk menurunkan 70 persen sampah plastik di laut pada tahun 2025 melalui pengurangan sampah sebesar 30 persen dan penanganan sampah sebesar 70 persen (Perpres RI No 97 2017).
Mengatasi masalah sampah plastik di laut harus dimulai dengan pengelolaan sampah plastik di darat karena 80 persen sampah di lautan berasal dari darat (Perpres RI No 83 2018). Oleh sebab itu, Indonesia sedang menggalakkan suatu gerakan untuk mengurangi pemakaian plastik yang dinamakan gerakan diet plastik. Gerakan diet plastik bertujuan untuk menyadarkan masyarakat tentang bahaya yang ditimbulkan dari penggunaan plastik yang tidak terkontrol, serta untuk mengendalikan jumlah peredaran sampah plastik sehingga bisa mengurangi dampak buruk yang terjadi. Salah satu bentuk gerakan tersebut adalah membawa tumbler sendiri, tidak lagi menggunakan sedotan plastik, dan membawa kantong plastik sendiri. Pemakaian kantong plastik sekali pakai dapat menimbulkan masalah lingkungan di masa depan karena salah satu sifatnya yang baru akan terdegradasi setelah ribuan tahun. Inisiasi gerakan diet plastik diharapkan dapat membantu mengurangi timbunan sampah plastik sekali pakai langsung dari sumbernya.

Gerakan diet plastik adalah sebuah gerakan kepedulian lingkungan yang menawarkan gaya hidup ramah lingkungan. Gerakan diet plastik berhubungan dengan perubahan perilaku masyarakat menjadi lebih peduli terhadap lingkungan sekitarnya (Setiawan \& Fithrah, 2015). Lebih lanjut, dalam tinjauan perilaku terdapat faktor-faktor yang memengaruhi perubahan perilaku seseorang. Menurut Teori Behavioral Change Model yang diperkenalkan oleh Ramsey dan Rickson pada tahun 1976 antara lain adalah pengetahuan, sikap, dan perilaku (Ramsey \& Rickson, 1976).

Teori lain yang dikenal sebagai Environmentally Responsible Behavior (ERB), dipopulerkan oleh Hines, Hungerford dan Tomera pada tahun 1987, mengatakan bahwa perilaku individu bukan hanya dipengaruhi oleh pengetahuan saja, tetapi juga oleh niatnya untuk melakukan sesuatu. Teori lain adalah Teori Planned Behavior (TPB) yang dikenalkan oleh Ajzen pada tahun 1990, mengungkapkan bahwa perilaku seseorang dipengaruhi oleh sikap (attitude), norma subjektif, dan persepsi kontrol perilaku (Ajzen, 2002).

Seiring dengan pertumbuhan jumlah konsumen yang semakin sadar dan peduli terhadap isu-isu ekologi maka perkembangan penelitian di ranah perilaku konsumen yang berkaitan dengan lingkungan juga semakin berkembang. Perilaku konsumen yang sadar lingkungan dipengaruhi oleh gaya hidup (lifestyle) dan nilainilai lingkungan (environmental values) yang 
melekat pada diri konsumen (Fraj \& Martinez, 2006). Pengetahuan lingkungan (environmental knowledge, nilai-nilai lingkungan (environmental values), dan rasa tanggung jawab (responsibility feelings) secara bersama-sama berpengaruh pada niat berperilaku ramah lingkungan dan dapat memprediksi perilaku ramah lingkungan secara umum (Kaiser, Ranney, Hartig, \& Bowler, 1999).

Wujud gaya hidup ramah lingkungan adalah perilaku kehidupan sehari-hari yang tidak atau sedikit mencemari lingkungan, misalnya tidak membuang sampah sembarangan, mengurangi penggunaan kantong plastik, dan meminimalisasi timbunan sampah dari produk atau makanan yang dikonsumsi (Ismail, 2017). Perilaku ramah lingkungan dapat dianalisis melalui perilaku konsumen dan juga keadaan hati konsumen yang merefleksikan tingkat kesadaran lingkungan (Chan, Wong, \& Leung, 2008). Selain itu juga dapat dilihat dari sikap aktif untuk melakukan daur ulang dan kemauan membayar lebih untuk produk ramah lingkungan (Kaiser et al., 1999).

Sosialisasi dalam konteks penelitian ini adalah penyebaran informasi kepada masyarakat mengenai program diet plastik yang dilakukan oleh pemerintah Kota Bogor. Sosialisasi dianggap memiliki peranan sangat penting untuk memberikan informasi kepada masyarakat tentang dampak yang ditimbulkan oleh limbah plastik dan apa yang dapat masyarakat lakukan untuk mengurangi limbah plastik di lingkungan wilayah Kota Bogor.

Awareness atau rasa sadar penting untuk diteliti pengaruhnya terhadap perubahan perilaku ramah lingkungan seseorang. Individu yang memiliki kesadaran lingkungan yang cukup tinggi akan memiliki perilaku membeli barang ramah lingkungan, mengonsumsi buah organik, dan berpartisipasi dalam kegiatan daur ulang. Sikap peduli yang didasari oleh keyakinan menarik untuk diketahui pengaruhnya terhadap perilaku ramah lingkungan karena seseorang yang memiliki kecenderungan untuk melestarikan alam dan memiliki empati terhadap alam akan menunjukkan komitmen perilaku yang lebih baik terhadap perilaku ramah lingkungan.

Sosialisasi atau penyebarluasan informasi dapat dilakukan dengan berbagai cara seperti melalui media massa, media sosial, penyuluhan, kampanye, word of mouth, dan sebagainya. Luthfiana dan Kania (2014) menyatakan bahwa sosialisasi memiliki pengaruh positif terhadap pembentukan brand awareness. Sosialisasi dianggap memiliki peranan sangat penting untuk memberikan informasi kepada masyarakat tentang dampak yang ditimbulkan oleh limbah plastik dan apa yang dapat masyarakat lakukan untuk mengurangi limbah plastik. Peran pemerintah, swasta, maupun para aktivis lingkungan sangat dibutuhkan untuk sosialisasi dan mengampanyekan isu pelestarian lingkungan ini sehingga dapat meningkatkan pengetahuan dan kesadaran masyarakat secara lebih komprehensif dan merata di semua kalangan (Waskito \& Harsono, 2012). Hal ini lah yang menjadi dasar dugaan (H1) bahwa sosialisasi berpengaruh positif terhadap kesadaran ramah lingkungan.

Sosialisasi dilakukan agar konsumen memiliki pemahaman yang baik mengenai produk ramah lingkungan sehingga akan memiliki sikap yang positif terhadap perilaku ramah lingkungan. Sosialisasi dengan menggunakan informasi yang jelas akan meningkatkan kesadaran dan sikap (Novianti \& Kartika, 2017). Sosialisasi yang dilakukan dengan cara yang tepat akan berpengaruh terhadap keyakinan individu untuk berubah dan mengikuti apa yang menjadi subjek sosialisasi. Sosialisasi berpengaruh signifikan terhadap pembentukan sikap (Waskito \& Harsono, 2012). Oleh karenanya, hipotesa selanjutnya yang dibangun dalam penelitian ini (H2) adalah sosialiasi berpengaruh positif terhadap sikap.

Persepsi dan perilaku konsumen meningkat sejalan dengan sosialisasi yang dilakukan (Widyastuti, Said, Siswono, \& Firmansyah, 2019). Perubahan perilaku seseorang atau individu dapat terjadi dengan melakukan sosialisasi suatu program secara terus menerus dan pesan yang disampaikan sesuai dengan kebutuhan pelanggan. Sosialisasi secara terus menerus mengandung arti bahwa pesan yang disampaikan dilakukan secara berulang sehingga secara sadar atau tidak sadar tertanam dalam pikiran pendengarnya. Iklan suatu produk makanan yang dilakukan secara terus menerus akan memengaruhi niat beli konsumen (Sumarwan, Simanjuntak, \& Yurita, 2012).

Lebih lanjut, sosialisasi suatu pesan yang sesuai dengan kebutuhan pelanggan akan lebih mudah diterima dibandingkan dengan pesan yang pada dasarnya tidak dibutuhkan. Oleh sebab itu dalam mengubah perilaku perlu diperhatikan cara sosialisasi dan pesan yang disampaikan. Hal inilah yang menjadi dasar bagi pengembangan hipotesa berikutnya yaitu 
sosialisasi berpengaruh positif terhadap perilaku $(\mathrm{H} 3)$.

Pada saat ini sudah banyak orang yang sadar lingkungan sehingga mereka berani membayar lebih untuk produk yang ramah lingkungan. Sikap dan perilaku ramah lingkungan dipengaruhi oleh niat individu dan merupakan faktor penting dalam kesadaran ramah lingkungan individu. Studi yang dilakukan oleh Chan et al. (2008) menunjukkan bahwa kesadaran ramah lingkungan berpengaruh terhadap sikap dan perilaku ramah lingkungan. Hal senada juga diungkapkan oleh Aydin (2016) yang menyebutkan bahwa kesadaran dan sikap ramah lingkungan saling berhubungan. Oleh sebab itu, hipotesa keempat adalah kesadaran ramah lingkunganberpengaruh positif terhadap sikap ramah lingkungan $(\mathrm{H} 4)$.

Menurut Waskito dan Harsono (2012), sosialisasi dan kampanye isu lingkungan dapat meningkatkan kesadaran secara lebih komprehensif. Sosialisasi dilakukan agar konsumen memiliki pemahaman yang baik mengenai produk ramah lingkungan sehingga akan memiliki sikap yang positif terhadap perilaku ramah lingkungan. Oleh karenanya, salah satu hipotesa penelitian ini adalah bagaimana kesadaran ( $\mathrm{H} 5)$ dan sikap $(\mathrm{H} 6)$ tentang perilaku ramah lingkungan seseorang. Kesadaran ramah lingkungan memberikan dampak yang besar terhadap perilaku ramah lingkungan setiap individu. Hal ini disebabkan karena kesadaran ramah lingkungan seseorang dapat menguatkan perilaku ramah lingkungannya. Sebagai contoh individu yang memiliki kesadaran ramah lingkungan yang cukup tinggi akan membeli barang yang ramah lingkungan, mengonsumsi buah organik, dan berpartisipasi dalam kegiatan daur ulang (Kaiser et al., 1999).

Kesadaran atas manfaat program ramah lingkungan berperan penting terhadap perilaku ramah lingkungan seseorang. Kesadaran terhadap lingkungan hidup telah meningkatkan perilaku pengurangan penggunaan tas plastik (Ari \& Yilmaz, 2017). Chan et al. (2008) juga mengungkapkan bahwa kesadaran ramah lingkungan berpengaruh positif terhadap perilaku pembelian konsumen. Kesadaran secara signifikan berpengaruh posistif terhadap perubahan perilaku (Fraj \& Martinez, 2006). Oleh karenanya, $\mathrm{H} 5$ dalam penelitian ini adalah kesadaran berpengaruh positif terhadap perilaku ramah lingkungan. Selanjutnya, individu yang memiliki filosofi eco-centric, yaitu pribadi yang memiliki kecenderungan untuk melestarikan alam dan memiliki empati terhadap alam, menunjukkan komitmen dan sikap yang lebih baik terhadap perilaku ramah lingkungan. Hal inilah yang menjadi dasar bagi hipotesa terakhir dalam penelitian ini bahwa sikap ramah lingkungan akan berpengaruh positif terhadap perilaku ramah lingkungan.

Penelitian sebelumnya yang dilakukan oleh Novianti dan Kartika (2017) mengenai pengaruh pemasaran ramah lingkungan tentang kebijakan kantong plastik berbayar terhadap perilaku ramah lingkungan masyarakat Kota Bogor bertujuan untuk melihat respon masyarakat terhadap pemberlakuan kebijakan kantong plastik berbayar dan perilaku masyarakat dalam membawa kantong plastik sendiri. Pada penelitian tersebut tidak dilihat variabel-variabel lain yang berpengaruh terhadap perilaku ramah lingkungan. Oleh karena itu, penelitian ini dilakukan untuk menganalisis pengaruh variabel sosialisasi, awareness, dan attitude terhadap perilaku ramah lingkungan pada masyarakat Kota Bogor setelah adanya kebijakan Pemerintah Daerah Kota Bogor mengenai penggunaan kantong plastik.

\section{METODE}

Penelitian dilakukan di Kota Bogor dengan populasi adalah masyarakat Kota Bogor dengan kriteria dewasa atau sudah berumah tangga. Teknik pengambilan contoh yang dilakukan adalah non-probability sampling, yaitu teknik sampling yang tidak memberikan peluang atau kesempatan yang sama bagi setiap anggota populasi untuk dipilih menjadi contoh. Jenis pengambilan contoh yang digunakan adalah convenience, yaitu pemilihan contoh karena faktor kemudahan bagi peneliti, dalam hal ini contoh dipilih karena berada pada waktu dan tempat yang tepat. Sebaran contoh meliputi masyarakat yang berada di wilayah Kecamatan Bogor Utara, Kecamatan Bogor Tengah, Kecamatan Bogor Selatan, dan Kecamatan Bogor Timur. Pengambilan data dilakukan secara online menggunakan media WhatsApp dengan menyebarkan kuesioner penelitian yang sudah disusun dalam google form.

Penentuan jumlah contoh dalam penelitian ini mengikuti rule of thumb dari analisis SEM, yaitu lima sampai sepuluh kali jumlah indikator yang diobservasi. Jumlah indikator dalam penelitian ini adalah 20, oleh karena itu jumlah contoh minimum yang dibutuhkan adalah 100 responden $(20$ indikator $x \quad 5)$. Untuk menyatakan kejelasan dari beberapa variabel 
yang akan diteliti dalam penelitian ini maka diperlukan batasan atau definisi secara operasional untuk setiap variabel yang digunakan.

Variabel pertama yang diteliti adalah sosialisasi. Definisi operasional variabel sosialisasi dalam penelitian ini adalah segala bentuk sosialisasi kegiatan diet plastik dengan indikator meliputi penggunaan media sosial, pemasangan spanduk/banner, pengadaan kantong belanja berbayar di toko swalayan, anjuran untuk membawa botol minum sendiri, dan juga kampanye gerakan diet plastik oleh pemerintah. Instrumen penelitian yang dibuat berupa lima pertanyaan yang dijawab dengan menggunakan skala Likert: 1=sangat tidak setuju, 2=tidak setuju, $3=$ cukup setuju, $4=$ setuju, dan $5=$ sangat setuju.

Variabel kedua adalah kesadaran (awareness). Definisi operasional variabel kesadaran adalah segala bentuk dukungan dan kepedulian konsumen terhadap kegiatan diet plastik dengan indikator meliputi membawa tas belanja sendiri, membawa botol minum sendiri, tidak menggunakan sendok plastik sekali pakai, tidak membeli makanan yang dibungkus plastik, dan juga membawa sedotan sendiri. Instrumen penelitian yang dibuat untuk variabel kesadaran berupa lima pertanyaan yang dijawab dengan menggunakan skala Likert: 1=sangat tidak setuju, 2=tidak setuju, 3=cukup setuju, 4=setuju, dan $5=$ sangat setuju.

Variabel ketiga adalah sikap (attitude). Definisi operasional variabel sikap adalah sikap konsumen terhadap kegiatan diet plastik dengan indikator meliputi membawa tas belanja sendiri merasa biasa saja, membawa botol minum sendiri merasa lebih nyaman, membawa sendok sendiri adalah hal yang baik, memilih membawa tempat makan sendiri daripada membeli makanan yang dibungkus plastik, dan juga membiasakan diri untuk membawa sedotan sendiri. Instrumen penelitian yang dibuat untuk variabel sikap berupa lima pertanyaan yang dijawab dengan menggunakan skala Likert: 1=sangat tidak setuju, 2=tidak setuju, 3=cukup setuju, $4=$ setuju, dan $5=$ sangat setuju.

Variabel keempat adalah perilaku (behavior). Definisi operasional variabel perilaku adalah tindakan ramah lingkungan yang dilakukan konsumen dengan indikator meliputi membawa tas sendiri pada saat belanja, membawa botol minum sendiri, membawa sendok sendiri, membawa tempat makan sendiri, dan membawa sedotan sendiri. Instrumen penelitian yang dibuat untuk variabel perilaku berupa lima pertanyaan yang dijawab dengan menggunakan skala Likert: $1=$ tidak pernah, 2=pernah, 3=jarang, 4=sering, dan 5=selalu.

Selanjutnya, uji validitas dan reliabilitas dilakukan terhadap setiap konstruk atau model pengukuran. Validitas berhubungan dengan apakah suatu variabel dapat mengukur apa yang seharusnya diukur. Validitas juga menyangkut tingkat akurasi (keakuratan) yang dicapai oleh sebuah indikator dalam menilai sesuatu. Pada penelitian ini, pengujian validitas menggunakan Teknik Confirmatory Factor Analysis (CFA). CFA digunakan untuk menguji kemampuan indikator-indikator yang digunakan dalam menginformasikan sebuah variabel. Syarat sebuah indikator dikatakan valid yaitu jika nilai loading factor $\geq 0,50$ (Hair, Black, Babin, \& Anderson, 2010). Sementara itu, reliabilitas adalah ukuran mengenai konsistensi internal dari indikator-indikator sebuah konstruk yang menunjukkan derajat sampai di mana masing-masing indikator tersebut mengindikasikan sebuah konstruk/faktor laten yang umum. Reliabilitas yang tinggi menunjukkan bahwa indikator-indikator mempunyai konsistensi tinggi dalam mengukur konstruk latennya. Nilai batas yang digunakan untuk menilai sebuah tingkat reliabilitas yang dapat diterima adalah jika nilai Construct Reliability $(\mathrm{CR}) \geq 0,70$ dan nilai Variance Extracted (VE) $\geq 0,50$.

Tabel 1 Hasil uji validitas dan realibilitas

\begin{tabular}{lrrrr}
\hline Indikator & $\begin{array}{c}\text { Loading } \\
\text { factor }\end{array}$ & $\begin{array}{c}\mathrm{t}- \\
\text { value }\end{array}$ & $\begin{array}{c}\mathrm{VE} \geq \\
0,50\end{array}$ & $\begin{array}{c}\mathrm{CR} \geq \\
0,70\end{array}$ \\
\hline Sosialisasi1 & 0,91 & 17,64 & & \\
Sosialisasi2 & 0,53 & 8,38 & & \\
Sosialisasi3 & 0,83 & 15,17 & 0,53 & 0,84 \\
Sosialisasi4 & 0,62 & 10,05 & & \\
Sosialisasi5 & 0,68 & 11,51 & & \\
Kesadaran1 & 0,91 & & & \\
Kesadaran 2 & 0,93 & 23,58 & & \\
Kesadaran 3 & 0,77 & 15,13 & 0,62 & 0,89 \\
Kesadaran 4 & 0,59 & 10,06 & & \\
Kesadaran 5 & 0,67 & 12,11 & & \\
Sikap1 & 0,65 & & & \\
Sikap 2 & 0,77 & 10,73 & & \\
Sikap 3 & 0,76 & 10,62 & 0,51 & 0,83 \\
Sikap 4 & 0,79 & 10,93 & & \\
Sikap 5 & 0,56 & 8,11 & & \\
Perilaku1 & 0,77 & & & \\
Perilaku 2 & 0,85 & 13,85 & & \\
Perilaku 3 & 0,59 & 9,01 & 0,59 & 0,88 \\
Perilaku 4 & 0,85 & 13,95 & & \\
Perilaku 5 & 0,77 & 12,27 & & \\
\hline Keterangan: & VE=variance & extracted; & CR=construct \\
reliability & \multicolumn{5}{c}{0.5} &
\end{tabular}


Hasil uji validitas menunjukkan semua nilai loading factor $\geq 0,50$, artinya bahwa seluruh pernyataan yang digunakan dalam penelitian ini mampu untuk mengukur semua variabel yang diteliti. Hasil uji reliabilitas menunjukkan semua nilai $\mathrm{VE} \geq 0,50$ dan nilai $C R \geq 0,70$, artinya bahwa seluruh pernyataan yang digunakan dalam kuesioner memiliki tingkat keandalan untuk ditanyakan kepada responden.

\section{HASIL}

\section{Karakteristik Demografi}

Jumlah responden yang terlibat dalam penelitian ini adalah sebanyak 223 orang responden, terdiri dari laki-laki dan perempuan dewasa yang tinggal di empat kecamatan di
Kota Bogor. Jumlah responden perempuan lebih banyak dibandingkan dengan responden laki-laki. Distribusi responden berdasarkan usia bervariasi mulai dari usia 17 tahun sampai di atas 45 tahun, dengan jumlah responden yang paling banyak adalah pada rentang usia 31-45 tahun sebesar 43 persen. Distribusi responden berdasarkan pendidikan terkonsentrasi paling banyak dengan latar belakang diploma/sarjana yaitu sebesar 89 persen. Sebaran responden berdasarkan pekerjaan dibagi dalam empat kelompok yaitu Pegawai Negeri Sipil (PNS), karyawan swasta, wirausaha, dan ibu rumah tangga dengan jumlah responden yang paling banyak adalah karyawan swasta sebesar 43 persen. Tingkat pengeluaran kebutuhan pokok responden dalam satu bulan paling banyak berada pada kisaran angka Rp3.000.000,00Rp7.000.000,00.

0,16

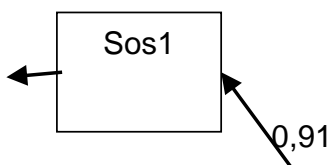

0,72

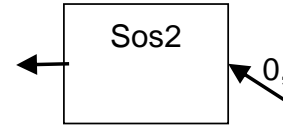

0,31

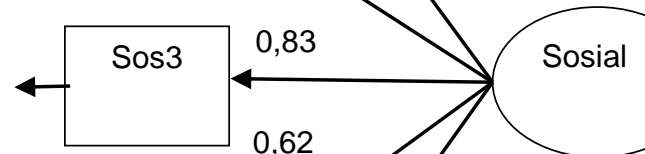

0,62

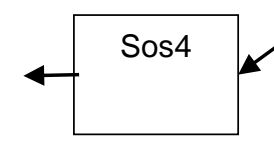

0,62

0,53

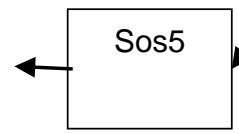

\section{0,68}
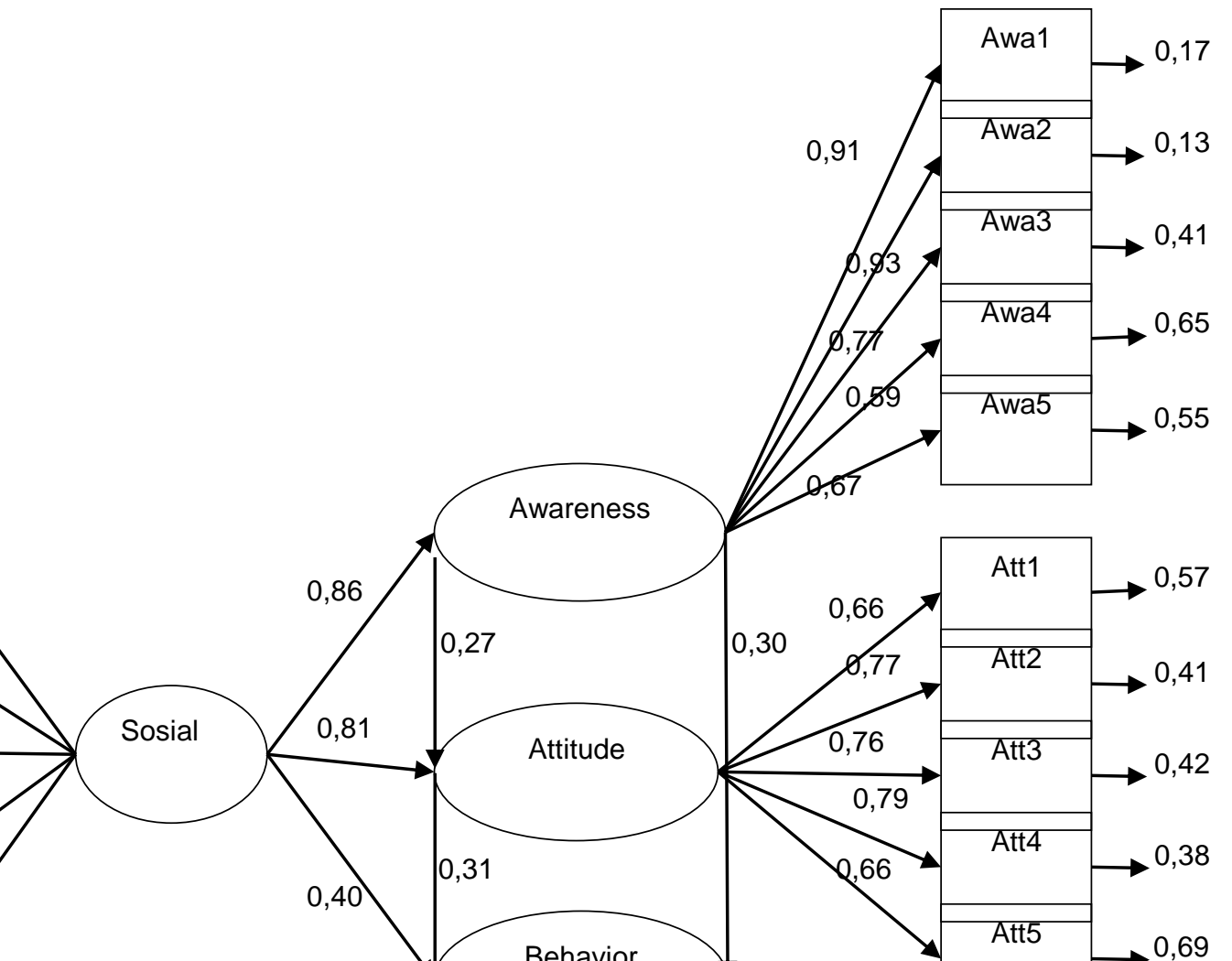
Berdasarkan model struktural dan nilai loading factor pada Gambar 1, variabel sosialisasi memberikan pengaruh terbesar pada indikator sosialisasi melalui media sosial dengan nilai loading factor sebesar 0,91 . Variabel kesadaran paling berpengaruh terhadap indikator membawa botol minum sendiri dapat mencegah kerusakan lingkungan dengan nilai loading factor sebesar 0,93. Sementara itu, variabel sikap memberikan pengaruh terbesar pada indikator lebih baik membawa tempat makan sendiri daripada membeli makanan dengan pembungkus plastik dengan nilai loading factor sebesar 0,79. Selanjutnya, variabel perilaku paling berpengaruh terhadap indikator membawa botol minum sendiri pada saat melakukan perjalanan dan membawa tempat makan pada saat melakukan perjalanan. Kedua indikator tersebut memiliki nilai loading factor yang sama yaitu 0,85 .

Selanjutnya dilakukan statistik uji-t pada setiap variabel laten untuk melihat signifikansi antara semua koefisien. Gambar 2 menunjukkan bahwa semua nilai t yang diperoleh lebih dari nilai t-hitung yaitu sebesar 1,96 yang merupakan nilai $\mathrm{t}$-kritis dengan taraf nyata sebesar 0,05. Oleh karena itu, dapat disimpulkan bahwa semua nilai koefisien pada model struktural penelitian dinyatakan signifikan.
7,69

10,39

9,52

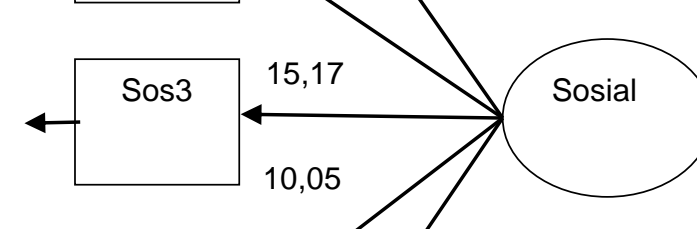

10,30

10,18

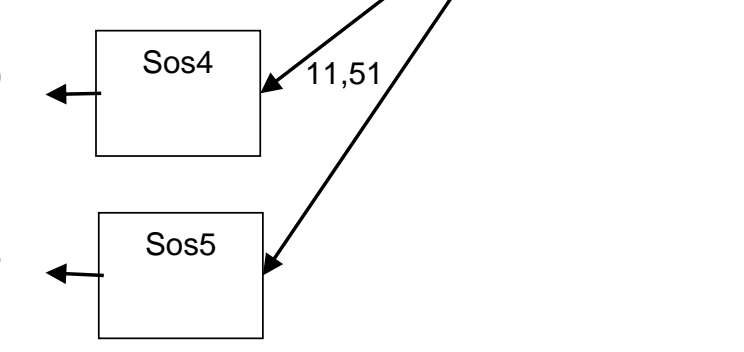

Keterangan:

Chi-square $=1318,28, \mathrm{df}=164, \mathrm{RMSEA}=0,178$

Sos $=$ Sosialisasi

Awa $=$ Awareness

Att $=$ Attitude

Bhv $=$ Behavior

Gambar 2 Model struktural dan nilai statistik uji t

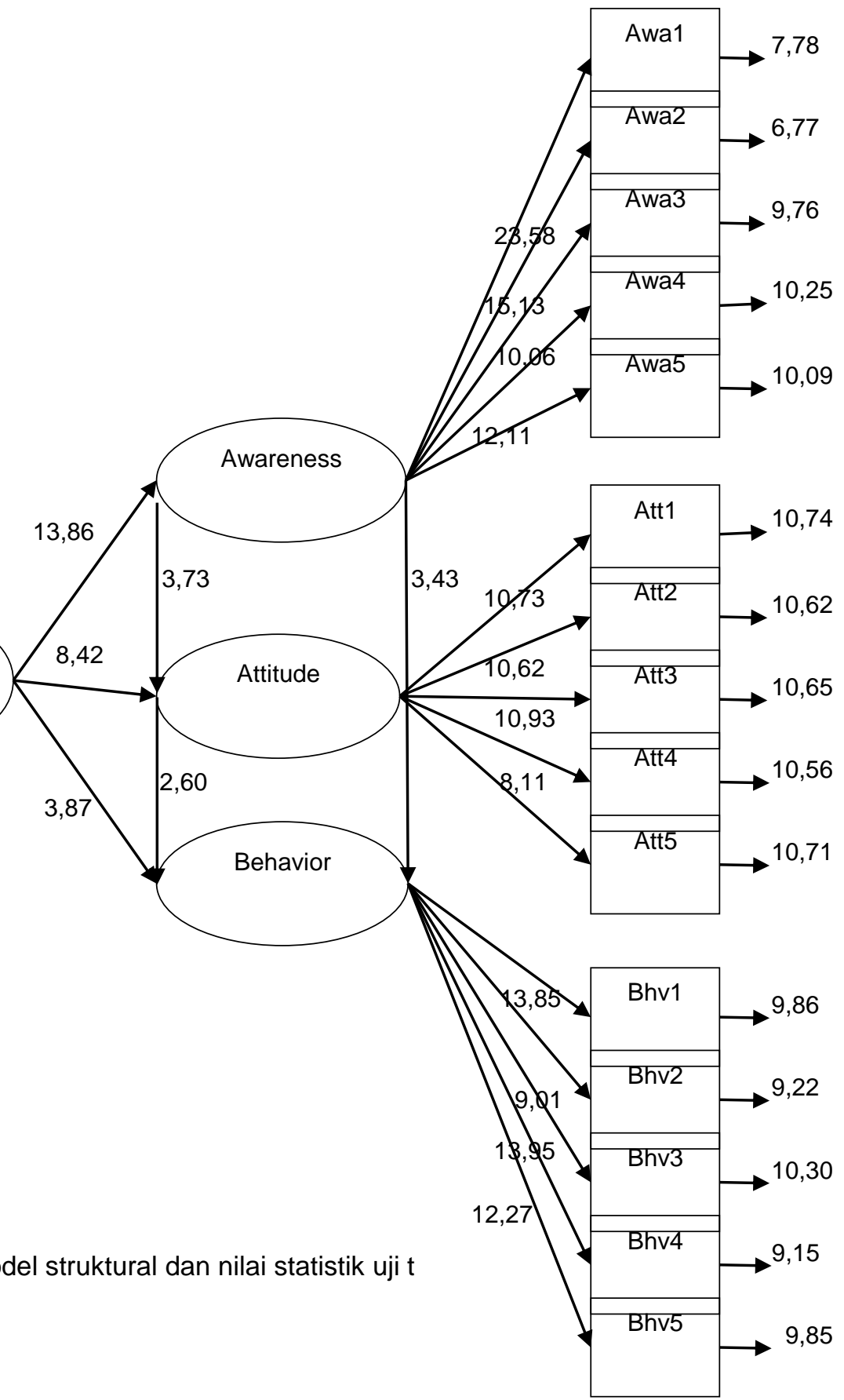


Tabel 2 Hasil uji kesesuaian model

\begin{tabular}{llrl}
\hline $\begin{array}{c}\text { Kriteria } \\
\text { kesesuaian }\end{array}$ & Nilai standar & Hasil & Kesimpulan \\
\hline $\mathrm{NFI}$ & $\geq 0,90$ & 0,91 & Good fit \\
$\mathrm{CFI}$ & $\geq 0,90$ & 0,92 & Good fit \\
$\mathrm{IFI}$ & $\geq 0,90$ & 0,92 & Good fit \\
$\mathrm{RFI}$ & $\geq 0,90$ & 0,90 & Good fit \\
$\mathrm{RMR}$ & $\leq 0,05$ & 0,03 & Good fit \\
\hline
\end{tabular}

Keterangan: $\mathrm{NFI}=$ Normed Fit Index; $\mathrm{CFI}=$ Comparative Fit Index; IFI= Incremental Fit Index; RFI= Relative Fit Index $\mathrm{RMR}=$ Root Mean Square Residual

Pengujian model SEM secara keseluruhan adalah menguji apakah model SEM secara keseluruhan cocok/fit terhadap data contoh. Pengujian ini dilakukan dengan membandingkan antara matriks kovarian contoh dan matriks kovarian estimasi model SEM. Uji kesesuaian model dilakukan dengan melihat lima indeks goodness of fit, yaitu Comparative Fit Index (CFI), Normed Fit Index (NFI), Incremental Fit Index (IFI), Relative Fit Index (RFI) dan Root Mean Square Residual (RMR). CFI yaitu perbandingan nilai chi-square dari model hipotesis dengan satu nilai dari null model atau baseline model. NFI merupakan ukuran perbandingan model yang diusulkan dengan null model. IFI digunakan untuk mengatasi kerumitan dan banyaknya contoh. $\mathrm{RFI}$ merupakan turunan dari NFI dan $\mathrm{CFI}$.

Hasil pengolahan data untuk menunjukkan adanya kesesuaian dengan tingkat kecocokan yang baik diperlihatkan pada Tabel 2 . Pengujian Goodness of Fit menunjukkan nilai Comparative Fit Index (CFI) sebesar 0,92 $\geq$ 0,90 yang artinya model yang dihasilkan sudah good fit. Begitu juga pengujian nilai Normed Fit Index (NFI) sebesar $0,91 \geq 0,90$ artinya model telah good fit. Penggunaan kriteria Goodness of Fit yang lain yaitu Incremental Fit Index (IFI) dengan nilai $0,92 \geq 0,90$, Relative Fit Index (RFI) dengan nilai $0,90 \geq 0,90$ dan Root Mean Square Residual (RMR) dengan nilai 0,03 $\leq$ 0,05 yang artinya model yang dihasilkan sudah good fit. Berdasarkan nilai koefisien dari Tabel 2 dapat dikatakan bahwa model sudah memenuhi syarat kesesuaian yang baik (good fit) sehingga model struktur tidak perlu dimodifikasi.

\section{Uji Hipotesis}

Hubungan antarvariabel untuk menguji hipotesis dalam penelitian ini dapat diketahui dengan melakukan uji signifikansi dengan tingkat kepercayaan 95 persen dan nilai standar t-value sebesar 1,96. Hasil uji signifikansi antar variabel laten disajikan pada Tabel 3.
Tabel 3 Hasil uji hipotesis

\begin{tabular}{lccl}
\hline \multicolumn{1}{c}{ Hipotesis } & $\begin{array}{c}\text { t-hit } \\
>1,96\end{array}$ & $\begin{array}{c}\text { Loading } \\
\text { factor }\end{array}$ & $\begin{array}{c}\text { Kesimpul } \\
\text { an }\end{array}$ \\
\hline $\begin{array}{l}\text { H1: Sosialisasi } \\
\rightarrow \text { Kesadaran }\end{array}$ & 13,86 & 0,86 & $\begin{array}{l}\text { Hipotesis } \\
\text { Diterima }\end{array}$ \\
H2: Sosialisasi & 8,42 & 0,81 & $\begin{array}{l}\text { Hipotesis } \\
\text { Diterima }\end{array}$ \\
$\rightarrow$ Sikap & & 0,40 & $\begin{array}{l}\text { Hipotesis } \\
\text { Diterima }\end{array}$ \\
H3: Sosialisasi & 3,87 & Perilaku & Hipotesis \\
$\rightarrow$ H4: Kesadaran & 3,73 & 0,27 & $\begin{array}{l}\text { Diterima } \\
\text { Dikap }\end{array}$ \\
$\rightarrow$ Sik: Kesadaran & 3,43 & 0,30 & $\begin{array}{l}\text { Hipotesis } \\
\text { Diterima }\end{array}$ \\
$\rightarrow$ Perilaku & & 0,31 & $\begin{array}{l}\text { Hipotesis } \\
\text { Diterima }\end{array}$ \\
$\begin{array}{l}\text { H6: Sikap } \rightarrow \\
\text { Perilaku }\end{array}$ & 2,60 & \\
\hline
\end{tabular}

Keterangan: t-hit: merupakan nilai t dari perhitungan SEM; 1,96: merupakan nilai standar t-value

Seperti yang tersaji di Tabel 3 , sosialisasi berpengaruh positif sebesar 0,86 terhadap kesadaran, artinya semakin baik sosialisasi yang dilakukan maka akan semakin baik kesadaran ramah lingkungan yang terbentuk pada konsumen. Selain itu, sosialisasi juga berpengaruh positif terhadap sebesar 0,81 terhadap sikap, artinya semakin baik sosialisasi yang dilakukan maka akan semakin baik sikap ramah lingkungan yang terbentuk pada konsumen. Selanjutnya, sosialisasi juga berpengaruh positif sebesar 0,40 terhadap perilaku, artinya semakin baik sosialisasi yang dilakukan maka akan semakin baik perilaku ramah lingkungan yang terbentuk pada konsumen.

Selain itu, Tabel 3 juga menemukan bahwa kesadaran berpengaruh positif sebesar 0,27 terhadap sikap, artinya semakin baik kesadaran ramah lingkungan yang dimiliki konsumen maka akan semakin baik sikap yang terbentuk. Kesadaran juga berpengaruh positif sebesar 0,30 terhadap perilaku, artinya semakin baik kesadaran ramah lingkungan yang dimiliki maka akan semakin baik perilaku yang terbentuk.

Selain kesadaran, sikap juga menunjukkan pengaruh yang positif sebesar 0,31 terhadap perilaku, artinya semakin baik sosialisasi yang dilakukan maka akan semakin baik perilaku ramah lingkungan yang terbentuk. Semua hipotesis diterima karena semua nilai t hitung lebih besar dari t table (Tabel 3).

\section{Pengaruh Langsung dan Tidak Langsung}

Variabel laten eksogen dapat memengaruhi secara langsung maupun secara tidak langsung terhadap variabel laten endogen. Pengaruh langsung dapat dilihat melalui nilai loading factor pada model struktural. Pengaruh 
langsung merupakan kondisi yang mana variabel laten eksogen memengaruhi variabel laten endogen tanpa melalui variabel perantara. Sementara itu, pengaruh tidak langsung adalah pengaruh variabel laten eksogen terhadap variabel laten endogen melalui variabel perantara. Pengaruh langsung dan pengaruh tidak langsung serta pengaruh total antara variabel laten eksogen dengan variabel laten endogen ditentukan berdasarkan hasil output analisis data.

Lebih lanjut, pengaruh tidak langsung bisa juga dihitung secara manual dengan mengalikan masing-masing loading factor antarvariabel. Sementara itu, pengaruh total dihitung secara manual dengan menambahkan semua loading factor pengaruh langsung dan tidak langsung (Tabel 4).

Variabel-variabel laten endogen pada penelitian ini adalah adalah kesadaran, sikap, dan perilaku, sedangkan variabel eksogen adalah sosialisasi. Berdasarkan hasil output lisrel SEM pada Tabel 4, diketahui pengaruh langsung variabel laten sosialisasi terhadap variabel laten kesadaran adalah 0,86; pengaruh langsung variabel laten sosialisasi terhadap variabel laten sikap adalah 0,81; dan pengaruh langsung variabel laten sosialisasi terhadap variabel laten perilaku adalah 0,40.

Sementara itu, pengaruh tidak langsung sosialisasi terhadap perilaku melalui kesadaran dan sikap adalah 0,57 ternyata lebih besar daripada pengaruh langsung sosialisasi terhadap perilaku. Hal ini menunjukkan bahwa terbentuknya perilaku ramah lingkungan lebih besar dampaknya melalui pengaruh tidak langsung variabel laten eksogen sosialisasi melalui variabel laten endogen kesadaran dan sikap. Sementara itu, pengaruh total sosialisasi terhadap perilaku melalui variabel kesadaran dan sikap adalah sebesar 0,97.

Tabel 4 Pengaruh langsung, pengaruh tidak langsung, dan pengaruh total variabel laten eksogen terhadap variabel laten endogen

\begin{tabular}{lrrrr}
\hline \multicolumn{1}{c}{$\begin{array}{c}\text { Eksogen } \rightarrow \\
\text { endogen }\end{array}$} & $\begin{array}{r}\text { Pengaruh } \\
\text { langsung }\end{array}$ & $\begin{array}{c}\text { Pengaruh } \\
\text { tidak } \\
\text { langsung }\end{array}$ & $\begin{array}{c}\text { Pengaruh } \\
\text { total }\end{array}$ \\
\hline $\begin{array}{l}\text { Sosialisasi } \\
\text { kesadaran } \\
\text { Sosialisasi }\end{array}$ & $\rightarrow$ & 0,86 & & 0,86 \\
$\begin{array}{l}\text { sikap } \\
\begin{array}{l}\text { Sosialisasi } \\
\text { perilaku }\end{array}\end{array}$ & 0,81 & 0,23 & 1,04 \\
\hline
\end{tabular}

Keterangan:Tabel menunjukkan pengaruh antara variabel eksogen dan endogen

\section{PEMBAHASAN}

Penelitian ini memiliki responden perempuan yang lebih banyak daripada laki-laki. Selain itu, informasi usia responden merupakan hal penting yang perlu diketahui karena dengan usia yang berbeda akan menggambarkan selera konsumsi barang atau jasa yang berbeda (Sumarwan, 2011). Data sebaran responden berdasarkan usia dianalisis untuk mendapatkan gambaran statistik deskriptif (Wilopo, 1995). Distribusi responden berdasarkan usia didominasi oleh responden pada rentang usia 31-45 tahun yaitu sebesar 43 persen. Distribusi responden berdasarkan pendidikan terkonsentrasi paling banyak dengan latar belakang diploma/sarjana, yaitu sebesar 89 persen. Distribusi responden berdasarkan pekerjaan didominasi oleh karyawan swasta. sementara itu, distribusi responden berdasarkan tingkat pengeluaran dalam satu bulan didominasi oleh masyarakat dengan tingkat pengeluaran Rp3.000.000 sampai dengan Rp7.000.000 setiap bulannya.

Hasil uji analisis SEM menunjukkan bahwa variabel sosialisasi berpengaruh terhadap kesadaran. Sosialisasi memiliki peranan penting untuk meningkatkan pengetahuan dan kesadaran masyarakat secara lebih komprehensif dan merata di semua kalangan tentang dampak yang ditimbulkan oleh limbah plastik dan apa yang dapat masyarakat lakukan untuk mengurangi limbah plastik di lingkungan wilayah Kota Bogor (Waskito \& Harsono, 2012). Hasil penelitian ini sejalan dengan hasil penelitian yang dilakukan oleh Luthfiana dan Kania (2014) yang menyatakan bahwa sosialisasi memiliki pengaruh positif terhadap pembentukan brand awareness. Penelitian lain yang dilakukan oleh Novianti dan Kartika (2017) juga menemukan bahwa penyampaian informasi yang jelas akan meningkatkan kesadaran dan sikap masyarakat untuk berpartisipasi dalam perilaku ramah lingkungan khususnya dalam penerapan kebijakan kantong plastik berbayar. Penelitian lain yang dilakukan oleh Boediono, Sitawati, dan Harjanto (2018) juga menemukan bahwa sosialisasi pelaporan pajak telah meningkatkan kesadaran dan perilaku patuh wajib pajak. Penelitian ini membuktikan bahwa sosialisasi memiliki pengaruh positif dan signifikan terhadap pembentukan kesadaran ramah lingkungan konsumen.

Penelitian ini menunjukkan, sosialisasi memiliki pengaruh positif dan signifikan terhadap pembentukan sikap ramah lingkungan. Temuan tersebut sejalan dengan pendapat Waskito dan 
Harsono (2012) yang mengungkapkan bahwa sosialisasi berpengaruh signifikan terhadap pembentukan sikap. Sosialisasi dilakukan agar konsumen memiliki pemahaman yang baik mengenai produk ramah lingkungan dan memiliki sikap yang positif terhadap perilaku ramah lingkungan. Sosialisasi yang dilakukan dengan cara yang tepat akan berpengaruh terhadap keyakinan individu untuk berubah dan mengikuti apa yang menjadi subjek sosialisasi. Hal ini sejalan dengan hasil penelitian Novianti dan Kartika (2017) yang mengungkapkan bahwa penyampaian informasi yang jelas akan meningkatkan kesadaran dan sikap masyarakat untuk berpartisipasi dalam perilaku ramah lingkungan yang terkait dengan penerapan kebijakan kantong plastik berbayar. Sosialisasi yang dilakukan dengan cara yang tepat akan berpengaruh terhadap keyakinan individu untuk berubah dan mengikuti apa yang menjadi subjek sosialisasi.

Selain itu, penelitian ini juga membuktikan bahwa sosialisasi memiliki pengaruh positif dan signifikan terhadap pembentukan perilaku ramah lingkungan. Sosialisasi dilakukan agar konsumen memiliki pemahaman yang baik mengenai produk ramah lingkungan sehingga akan memiliki sikap yang positif terhadap perilaku ramah lingkungan. Persepsi dan perilaku konsumen meningkat sejalan dengan sosialisasi yang dilakukan (Widyastuti et al., 2019). Merubah perilaku seseorang atau individu dapat dilakukan dengan melakukan sosialisasi suatu program secara terus menerus sehingga secara sadar atau tidak sadar tertanam dalam pikiran pendengarnya. Sosialisasi iklan suatu produk yang dilakukan secara terus menerus akan memengaruhi niat beli konsumen (Sumarwan et al., 2012).

Analisis lebih rinci yang dilakukan dalam penelitian ini juga menemukan bahwa kesadaran memiliki pengaruh positif dan signifikan terhadap pembentukan sikap ramah lingkungan. Individu yang sudah memiliki kesadaran yang baik terhadap lingkungan maka akan memperlihatkan sikap yang lebih bertanggung jawab terhadap lingkungan. Semakin tinggi tingkat kesadaran individu maka akan semakin baik pula sikap individu tersebut terhadap lingkungan. Studi yang dilakukan oleh Chan et al. (2008) menunjukkan bahwa kesadaran akan kelestarian lingkungan berpengaruh terhadap sikap dan perilaku ramah lingkungan. Penelitian yang dilakukan oleh Aydin (2016) mengkonfirmasi bahwa kesadaran akan kelestarian lingkungan dan sikap ramah lingkungan saling berhubungan.
Selain itu, penelitian ini juga membuktikan bahwa kesadaran memiliki pengaruh positif dan signifikan terhadap pembentukan perilaku ramah lingkungan. Kesadaran seseorang tentang kelestarian lingkungan dapat menguatkan perilaku ramah lingkungan yang dilakukan seseorang. Sebagai contoh, individu yang memiliki kesadaran lingkungan yang cukup tinggi akan membeli barang yang ramah lingkungan serta mengonsumsi buah organik dan berpartisipasi dalam kegiatan daur ulang (Kaiser et al., 1999). Hal tersebut menegaskan pentingnya peran program ramah lingkungan terhadap perilaku ramah lingkungan seseorang (Fraj \& Martinez, 2006).

Selain kesadaran, penelitian ini juga membuktikan bahwa sikap ramah lingkungan memiliki pengaruh positif dan signifikan terhadap pembentukan perilaku ramah lingkungan. Seseorang yang memiliki sikap yang cenderung peduli untuk melestarikan alam akan menunjukkan komitmen yang lebih baik terhadap perilaku ramah lingkungan. Sikap yang baik terhadap lingkungan hidup telah meningkatkan perilaku untuk mengurangi penggunaan tas plastik (Ari \& Yilmaz, 2017). Temuan ini sejalan dengan hasil penelitian Chan et al. (2008) yang juga menemukan keterkaitan erat antara sikap dan perilaku ramah lingkungan.

\section{SIMPULAN DAN SARAN}

Penelitian ini membuktikan bahwa green behavior dipengaruhi oleh variabel sosialisasi, awareness dan attitude. Variabel sosialisasi memiliki pengaruh positif dan signifikan terhadap variabel awareness, attitude dan behavior. Variabel awareness memiliki pengaruh positif dan signifikan terhadap variabel attitude dan behavior. Variabel attitude terbukti memiliki pengaruh positif dan signifikan terhadap behavior sehingga dapat disimpulkan bahwa seluruh hipotesis penelitian sudah teruji dan dapat di terima. Lebih lanjut, sosialisasi merupakan variabel yang lebih dominan dalam membentuk dan meningkatkan green consumer behavior, artinya semakin baik sosialisasi yang dilakukan maka akan semakin tinggi kesadaran green consumer behavior masyarakat yang terbentuk.

Lebih lanjut, dalam rangka meningkatkan green consumer behavior dapat dilakukan dengan cara mengoptimalkan aspek sosialisiasi melalui media sosial secara selektif dan konsisten. Selektif dalam menentukan target konsumen, selektif dalam menentukan media dan konsisten dalam memperbaharui konten media. 
Melakukan kegiatan-kegiatan yang menarik dengan memanfaatkan konten media sosial, seperti kompetisi foto selfie, membuat artikel green consumer behavior dan lain sebagainya. Kegiatan lain untuk meningkatkan green consumer behavior adalah melalui pemasangan spanduk atau banner sosialisasi green consumer behavior di tempat-tempat strategis dan jumlahnya diperbanyak.

Penelitian ini memiliki keterbatasan dalam hal jumlah sampel yang terlibat dalam penelitian. Oleh sebab itu, saran bagi penelitian selanjutnya agar dapat menambahkan jumlah serta memperluas cakupan sampel sehingga semakin banyak masyarakat Kota Bogor yang terlibat dan hasil penelitian dapat lebih komprehensif.

\section{DAFTAR PUSTAKA}

[Perpres RI] Peraturan Presiden Republik Indonesia. (2017). Peraturan Presiden Republik Indonesia Nomor 97 Tahun 2017 tentang Kebijakan dan Strategi Nasional Pengelolaan Sampah Rumah Tangga dan Sampah Sejenis Sampah Rumah Tangga. Diambil dari https://peraturan.bpk.go.id/ Home/Details/73225/perpres-no-97-tahun2017.

[Perpres RI] Peraturan Presiden Republik Indonesia. (2018). Peraturan Presiden Republik Indonesia Nomor 83 Tahun 2018 tentang Penanganan Sampah Laut. Diambil dari https://peraturan.bpk.go.id/ Home/Details/94716/perpres-no-83-tahun2018.

Ajzen, I. (2002). Perceived behavioral control, self-efficacy, locus of control, and the theory of planned behavior. Journal of applied social psychology, 32(4), 665-683. doi:10.1111/j.1559-1816.2002.tb00236.x.

Ari, E., \& Yilmaz, V. (2017). Consumer attitudes on the use of plastic and cloth bags. Environmental Development Sustain, 19(7), 1219-1234. doi:10.1007/s10668016-9791-x.

Aydin, H. (2016). Some determinants of green consumption behavior: A study on green consumers. Journal of Environmental Management and Tourism, 7(4), 609-618. doi:10.14505/jemt.v7.4(16).07.

Boediono, G. T., Sitawati, R., \& Harjanto, S. (2018). Analisis pengaruh sosialisasi perpajakan terhadap kepatuhan wajib pajak dengan kesadaran sebagai variabel mediasi. Jurnal Penelitian Ekonomi dan
Bisnis, 3(1),

doi:10.33633/jpeb.v3i1.2286.

22-38.

Chan, R. Y. K., Wong, Y. H., \& Leung, T. K. P. (2008). Applying ethical concepts to the study of green consumer behavior. Journal of Business Ethics, 79(2), 469-481. doi:10.1007/s10551-007-9410-8.

Fraj, E., \& Martinez, E. (2006). Environmental values and lifestyles as determining factors of ecological consumer Behavior: an empirical analysis. Journal of Consumer Marketing, 23(3), 133-144. doi:10.1108/07363760610663295.

Geyer, R., Jambeck, J. R., \& Law, K. L. (2017). Production, use and fate of all plastics ever made. Science advance, 3(7), 1-5. doi:10.1126/sciadv.1700782.

Hair, J. F., Black, W. C., Babin, B. J., \& Anderson, R. E. (2010). Multivariate data analysis. New Jersey, US: Pearson Prentice Hall.

Ismail, O. A. (2017). Promosi kampanye diet kantong plastik oleh greeneration Indonesia. Jurnal IImu Politik dan Komunikasi, 7(1), 93-102. doi:10.34010/JIPSI.V7I1.335.

Jambeck, J. R., Geyer, R., Wilcox, C., Siegler, T. R., Perryman, M., Andrady, A., Narayan, R., \& Law, K. L. (2015). Plastic waste inputs from land into the ocean. Science, 347(6223), 768-770. doi:10.1126/science .1260352 .

Kaiser, F., Ranney, M., Hartig, T., \& Bowler, P. (1999). Ecological behavior, environmental attitude, and feelings of responsibility for the environment. European Psychologist, $4(2)$, 59-74. doi:10.1027//10169040.4.2.59.

Luthfiana, I., \& Kania, D. (2014). Pengaruh komunikasi pemasaran sosial terhadap brand awareness ombudsman Republik Indonesia. Journal Communication Spectrum, $\quad 4(1), \quad 24-42$. doi:10.36782/jcs.v4i1.1769.

Novianti, A. I., \& Kartika, L. (2017). Pengaruh green marketing kebijakan kantong plastik berbayar terhadap green behavior masyarakat Kota Bogor. Jurnal Riset Manajemen dan Bisnis, 2(1), 81-94. doi:10.36226/jrmb.v2i1.32.

Ramsey, C. E., \& Rickson, R. E. (1976). Environmental knowledge and attitudes. The Journal of Environmental Education, 8(1), 10-18. doi:10.1080/00958964 .1976 .9941552 . 
Schwarz, A. E., Ligthart, T. N., Boukris, E., \& Harmelen, T. (2019). Sources, transport, and accumulation of different types of plastic litter in aquatic environments: a review study. Marine Pollution Bulletin, 143, 92-100. doi:10.1016/j.marpolbul .2019.04.029.

Setiawan, B., \& Fithrah, D. (2015). Kampanye gerakan Indonesia diet kantong plastik dalam membentuk persepsi masyarakat Bandung. Jurnal Manajemen Komunikasi, 2(2), 102-117. doi:10.24198/jmk .v2i2.12909.

Sumarwan, U. (2011). Perilaku konsumen: teori dan penerapannya dalam pemasaran. Bogor, ID: Ghalia Indonesia.

Sumarwan, U., Simanjuntak, M., \& Yurita. (2012). Persepsi dan preferensi iklan memengaruhi niat beli anak pada produk makanan ringan. Jurnal ilmu Keluarga \&
Konsumen, 5(2), 185-192. doi:10.24156/ jikk.2012.5.2.186.

Waskito, J., \& Harsono, M. (2012). Gren consumer: deskripsi tingkat kesadaran dan kepedulian masyarakat joglosemar terhadap kelestarian lingkungan hidup. Jurnal Dinamika Manajemen, 3(1), 29-39. doi:10.15294/jdm.v3i1.2457.

Widyastuti, S., Said, M., Siswono, S., \& Firmansyah, D. A. (2019). Customer trust through green corporate image, green marketing strategy, and social responsibility: A case study. European Research Studies, 22(2), 83-99. doi:10.35808/ersj/1427.

Wilopo, S. A. (1995). Transisi demografi dan pembangunan berkelanjutan. Jurnal $\begin{array}{lll}\text { Populasi, } & \text { 6(1), }\end{array}$ doi:10.22146/jp.11443. 